\title{
"Tomar cuidado com o que eu falo": ser criança na escola, ficar e brincar em casa
}

\author{
"Be careful what I say": being children at school, staying and playing \\ at home
}

Regina Coeli Machado e Silva ${ }^{1}$

Marisa Elizabete Cassaro Godoy²

Resumo: O autoentendimento de crianças como resultado da participação ativa nas relações entre adultos que, direta ou indiretamente, participam das atividades de comércio transfronteiriço na travessia do rio Paraná, na fronteira entre Ciudad del Este, -Paraguai e Foz do Iguaçu, - Brasil, é o foco deste artigo. As percepções e significados aí construídos por elas foram apreendidos durante uma experiência etnográfica em uma escola pública de ensino fundamental. A interlocução se deu com os alunos moradores do bairro próximo ao rio, da faixa etária entre oito e doze anos, por meio de diferentes formas de comunicação oral, gestual e gráfica, como desenhos e histórias de vida. Exploramos as relações entre uma cosmologia jurídicopolítica (que define as relações entre diferentes atores sociais aí envolvidos) e um certo tipo de epistemologia que não concebe o autoentendimento das crianças como mera reprodução de práticas e saberes observados dos adultos. O que as crianças vivem, sabem e falam são respostas parciais a um modo de existência marcado por reticências e silêncios, trazidos pelas sutis modulações na comunicação entre nós. Ser criança, nesse contexto, é ficar e brincar em casa, sob controle e vigilância dos adultos e, fora do

\footnotetext{
${ }^{1}$ Universidade Estadual do Oeste do Paraná. Dra em Antropologia Social pelo Museu Nacional, professora do Mestrado e Doutorado em Letras / Mestrado e Doutorado Interdisciplinar Sociedade, Cultura e Fronteira. E-mail: coeli.machado@yahoo.com.br

2 Psicóloga, com mestrado interdisciplinar em Sociedade, Cultura e Fronteiras, professora da UDC (Centro Universitário Dinâmica das Cataratas (Anglo) e CESUFOZ (Centro de ensino Superior de Foz do Iguaçu). E-mail: godoy.mec@gmail.com.
}

Latitude, Vol. 10, nํㅡㄹ 2, pp. 287-319, 2016

DOI: https://doi.org/10.28998/2179-5428.20160206 
"Tomar cuidado com o que eu falo": ser criança na escola, ficar e brincar em casa

bairro, na escola ou em qualquer outro lugar, é manter, sempre que possível, sigilo sobre seu modo de vida.

Palavras Chave: Antropologia da criança; etnografia; fronteira; sigilo; comércio transfronteiriço

\begin{abstract}
This article focuses on the self- understanding among children as a result of active participation in relations with adults who, directly or indirectly, participate in trans-border commercial activities on the crossing of the Paraná River, on the border between Ciudad del Este, Paraguay and Foz do Iguaçu, Brazil. The perceptions and meanings there constructed by these children were collected during an ethnographic experience in a public elementary school. The dialogue took place with students living in the neighborhood adjacent to the river, ages $8-12$, through different forms of oral, nonverbal, and graphic communication, as patterns and stories of life. We explore the relations between a legal-political cosmology (that defines the relations between different social actors involved there) and a certain type of epistemology that does not conceive self-learning of children as a mere reproduction of observed practices and knowledge of adults. What the children live, know, and say are partial responses to a mode of existence marked by reservations and silence, brought out by subtle modulations in communication between ourselves. To be a child, in this context, is to stay and play at home, under adult control and supervision and, outside the neighborhood, the school, or in whichever other place, is to maintain, whenever possible, secrecy of one's mode of living.
\end{abstract}

Keywords: child anthropology; ethnography; border; secrecy; trans-border commercial activities

Compreendendo as crianças como atuantes e produtoras de significados, no contexto onde vivem, queremos apresentar neste artigo as formas de vida singulares de crianças afetadas pelas atividades do comércio transfronteiriço, na cidade de Foz do Iguaçu. Trata-se do transporte de mercadorias trazidas em barcos, pelo rio Paraná, a pé ou em carros pela travessia da fronteira entre o Paraguai e o Brasil, situado entre o "ilegal" e o "rotineiro", como aqui caracterizamos. Enfatizamos o autoentendimento de crianças cujos pais, ou adultos por elas responsáveis, 


\section{Regina Coeli Machado e Silva \\ Marisa Elizabete Cassaro Godoy}

vivem quase exclusivamente dessas atividades. Conversar com elas sobre esse modo de viver nos permitiu compreender como elas participam dessas atividades, resistem-lhes, entendem-nas e nos revelam as ambiguidades aí produzidas. Encontramo-nos com algumas dessas crianças, da faixa etária entre oito e doze anos, como alunos e alunas em uma escola pública de ensino fundamental, localizada em bairro próximo à Ponte da Amizade que liga os dois países. A interlocução se deu por meio de diferentes formas de comunicação oral, gráfica e gestual, como desenhos e histórias de vida. Nesse diálogo, indagávamos como as crianças interpretam e compreendem o contexto singular na convivência delas com pais, parentes, vizinhos e amigos que são discriminados pelas atividades de transporte de mercadorias, vivem sob ameaças constantes da polícia e enfrentam preconceitos ligados ao contrabando, veiculados por outros moradores e pelas mídias local e nacional. Elas também convivem de perto com outros adultos além do bairro, como professores da escola, gestores e técnicos de serviços sociais públicos, como psicólogos e assistentes sociais, além de outros atores sociais que "conhecem" sem conviver diretamente com eles, como os policiais que atuam no bairro.

Como moradores da cidade, somos todos afetados ${ }^{3}$, direta ou indiretamente, por formas de vida vinculadas ao comércio transfronteiriço. Assim, privilegiar o autoentendimento de crianças que emergiu da interlocução com elas em uma escola implicou levar adiante os limites e as possibilidades de compreensão desse assunto, excessivamente familiar. $\mathrm{O}$ desafio foi, então, buscar contrastar essa familiaridade por intermédio da vida e das ações das crianças explorando as relações entre uma cosmologia jurídico-política (que define as relações entre diferentes atores sociais aí envolvidos, como mostraremos a seguir) e um certo tipo de epistemologia que não concebe o autoentendimento das crianças como mera reprodução de práticas e saberes observados dos adultos, mas construído pela inescapável inserção infantil nas relações desse contexto. Esse

\footnotetext{
${ }^{3}$ Podemos não participar diretamente dessa rede particular de comércio, mas é essa mesma rede que nos insere no comércio local da cidade como "bons compradores" por ter salário regular (como funcionárias públicas) e cartão de crédito. Outra forma de sermos afetados se aproxima do dispositivo de conhecimento descrito por Favret-Saada (1990), pois "sabemos", quando não se pode falar, em que uma pessoa trabalha quando ela diz vagamente que trabalha no Paraguai.
} 
"Tomar cuidado com o que eu falo": ser criança na escola, ficar e brincar em casa

autoentendimento é resultado da participação ativa nessas relações e foi revelado em sua particularidade em interlocução conosco.

Organizamos a exposição deste artigo da seguinte forma: na primeira sessão apresentamos o interesse inicial que conduziu a etnografia e a redefinição desse interesse construída progressivamente desde as primeiras indagações a respeito da vida das crianças, cujos pais vivem do trabalho de transporte de mercadorias na fronteira, considerado ilegal. Nessa sessão evidenciamos que as restrições impostas a esse trabalho considerado ilegal foram as mesmas que nos impediram de conduzir a etnografia no bairro próximo à Ponte de Amizade, onde reside grande parte das pessoas que se dedicam a essa atividade e por onde passam parte das mercadorias trazidas do Paraguai. Isso redefiniu não só onde a etnografia teve lugar - na escola frequentada pelas crianças do bairro como também os meios de nos comunicarmos com elas, o que nos leva à segunda sessão do artigo, sobre o que as crianças vivem, sabem e falam por meio dos desenhos. Na terceira sessão, tentamos mostrar que se os desenhos foram um meio de entrar em diálogo, eles igualmente se tornaram respostas parciais a um modo de existência marcado por reticências e silêncios, trazidos pelas sutis modulações na comunicação entre nós. Finalmente, na quarta e última sessão, mostramos que o que as crianças da escola nos disseram é que ser criança neste contexto é ficar e brincar em casa, sob controle e vigilância dos adultos e, fora do bairro, na escola ou em qualquer outro lugar, é manter, sempre que possível, sigilo sobre seu modo de vida.

\section{O que as crianças vivem, sabem e nos falam por meio dos seus desenhos}

Como mencionado acima, privilegiar o autoentendimento de crianças que emergiu da interlocução com elas em uma escola implicou em um certo tipo de epistemologia que não concebe o auto entendimento das crianças como mera reprodução de práticas e saberes observados dos adultos, mas construído pela inescapável inserção infantil nas relações desse contexto. Esse autoentendimento foi resultado da participação ativa nessas relações e foi revelado em sua particularidade em interlocução conosco.

As implicações teórico-metodológicas decorrente dessa epistemologia podem ser compreendidas por meio da afirmação de Roy 


\author{
Regina Coeli Machado e Silva \\ Marisa Elizabete Cassaro Godoy
}

Wagner (2010) de que nossos modelos analógicos para interpretação são eles mesmos interpretados no processo de experiência etnográfica, com claras implicações para todos os envolvidos. Esse processo tornou-se visível desde as primeiras indagações sobre o tema. O ponto de partida foram as experiências iniciais de uma de nós como psicóloga, supervisora no estágio de Psicodiagnóstico Infantil, em atendimento clínico de crianças encaminhadas para o Centro de Psicologia Aplicada de uma das faculdades locais. Entre tantas crianças, em 2008, estava um menino de 8 anos, morador de um bairro às margens do rio Paraná. Ele parecia amedrontado e arredio durante o atendimento psicológico. Em um dos atendimentos grupais com outras crianças, disse: "Minha avó falou que é para eu tomar cuidado com o que falo por aqui", tornando explícita a razão pela qual demonstrava prudência ao expressar-se verbalmente: esconder o tipo de trabalho a que se dedica os avós. No entanto, expressava-se simbolicamente através de brinquedos como bonecos, carrinhos e blocos de madeira. Os desenhos dessa criança e de outras aí atendidas traziam situações tensas por elas vivenciadas entre adultos e, às vezes, expressavam claramente representando com os brinquedos, o trabalho cotidiano de transporte de mercadorias na fronteira. Assim, se o comércio transfronteiriço afeta a todos nós como moradores da cidade, para a vivência das crianças e dos adolescentes, moradores do bairro localizado nas margens do Rio Paraná, parecia ter um significado específico. Desde então começamos a nos perguntar como era o cotidiano vivido por essas crianças e isto nos instigou a querer nos aproximar mais delas em outras situações, fora da clínica.

Se o ponto de partida na clínica foram perguntas a respeito dos modos pelos quais as crianças conviviam entre os adultos em sua intimidade com moralidades contraditórias - se considerarmos o pai, ou os adultos por elas responsáveis, como figuras de autoridade e, ao mesmo tempo, figuras "fora da lei" pelos órgãos de fiscalização e de repressão ao trabalho de transporte de mercadorias ilegal - aos poucos as indagações foram sendo redirecionadas e focadas nas relações estabelecidas entre as crianças com os pais ou os adultos com os quais possuem vínculos, sobre como experimentam e entendem as moralidades conflitantes derivadas tanto do convívio quanto das ocupações dos adultos no bairro, desenvolvendo uma interpretação própria do bairro e da cidade. Com essa mudança de enfoque, começamos pela tentativa de frequentar os espaços do bairro onde houvesse crianças, mas, logo percebemos, revelou-se 
"Tomar cuidado com o que eu falo": ser criança na escola, ficar e brincar em casa

infrutífera. Uma das primeiras dificuldades enfrentadas foi a impossibilidade de estar no bairro, constatada na primeira e única vez em que lá estivemos, acompanhadas de uma assistente social e de uma psicóloga que fariam uma visita familiar. Foi quando observamos que o bairro é "fechado" e o acesso a ele é controlado por "olheiros" (categoria que nos referiremos à frente, que solicitam identificação de "estranhos" à rua, mesmo para os funcionários públicos das áreas da saúde e da assistência social. Assim, um dos caminhos tornados possíveis para estarmos entre as crianças foi o espaço escolar.

No espaço escolar na fronteira, como observamos em uma experiência etnográfica anterior (PIRES SANTOS et alli, 2015), o cotidiano das atividades de comércio pode parecer distante, mas é parte da rotina da escola pela constante interação com os pais e os adultos responsáveis pelas crianças. Também percebemos, no caso em escolas de ensino fundamental e médio, que os hiatos dissonantes do Estado-Nação, presentes na vida de pais, alunos, professores, parecem aí estar mais visíveis. Em uma primeira aproximação, imediata, o signo da presença do Estado-Nação (SILVA, 2013) é visível na preocupação oficial com a alfabetização e a educação no País. Se a escola é um dos lugares que nos faz cidadãos brasileiros - e a educação é vista como um direito fundamental do ideário da cidadania -é igualmente nela que verificamos uma cisão entre a cidadania e a condição vivida, experiência sobretudo desses grupos populares específicos, que vivem do trabalho de transportar mercadorias de Ciudad Del Este a Foz do Iguaçu. Assim, optamos pela escola como um local possível para se conhecer as formas de experimentação como indissociáveis do modo de vida nesse contexto, caracterizado pelas fronteiras incertas entre o legal e o ilegal. O ambiente escolar é entendido como um espaço indissociável da vida vivida no contexto de fronteira, pelos incessantes enfrentamentos entre vida (de trabalho) e direito (cidadania), vida (condição existencial) e forma de vida (ilegalidade), limites que são, ao mesmo tempo, deslizantes, dissolvidos e enrijecidos. No espaço físico da escola - onde se encontram jovens e crianças, professores, pais, gestores escolares, representantes judiciais e gestores de políticas públicas governamentais - emergem diversas práticas constitutivas desses limites (SILVA, 2015).

A experiência apresentada neste artigo ocorreu entre 2014 e 2015 em uma escola pública municipal, de ensino fundamental, que atende as crianças do bairro próximo à Ponte da Amizade. Os contatos iniciais se 


\section{Regina Coeli Machado e Silva \\ Marisa Elizabete Cassaro Godoy}

deram com a Diretora da escola que se interessou pelo tema proposto na pesquisa, sobretudo pelas dificuldades que ela observava entre os professores que, ao se depararem com o mundo singular, embora conhecido e trazido pelas crianças, não pode ser facilmente acolhido por transitar entre os discursos do que é legal e ilegal. Os professores tendem a não saber o que dizer e o que fazer diante de comentários dos alunos sobre o cotidiano vivido no bairro.

Como é próprio da etnografia, o tempo de convívio na escola ${ }^{4}$ foi dedicado a entrevistar professores, observar e tomar notas, estar com as crianças no pátio durante o recreio, acompanhá-las nas aulas de informática no laboratório, nas aulas de recreação e participar das atividades em sala de aula do $5^{\circ}$ ano do ensino fundamental, com 20 crianças de 8 a 12 anos de idade. Uma de nós foi apresentada às crianças como pesquisadora interessada em saber mais sobre elas e para isso lhes pedia a colaboração. Estar na escola quase diariamente aproximou nosso convívio, fazendo com que nossos interesses como pesquisadores fossem compartilhados ativamente pelas crianças, que assim participavam com entusiasmo das atividades propostas durante a etnografia. Uma delas foi a elaboração de desenhos com os seguintes temas: o que é a fronteira, o que veem na Ponte da Amizade e os quatro momentos de um dia. Durante a aula, cada uma das crianças descreveu o que havia desenhado e colocavam o próprio nome em seus desenhos, sem que pedíssemos. Alguns apresentavam legendas

${ }^{4} \mathrm{O}$ interesse pela etnografia na escola, com o foco nas interações entre alunos e professores na sala de aula, tem sido comum desde a década de 70 nas áreas da Educação e da Linguística Aplicada (André, 1997; Gasparin; 2015; Pires Santos e Cavalcanti, 2008 e Fritzen, 2008). O diálogo entre a Antropologia e a Educação em geral tem origens longíguas, com Boas, Ruth Benedict e Margareth Mead, como mostrou Gusmão, 1997. Paralelamente, e nem sempre desenvolvida dentro dessas áreas, há o que podemos denominar como sendo uma Antropologia da Cognição cujo interesse, por vezes, volta-se para as crianças ao tentar responder como o conhecimento é aprendido, construído, mantido e reformulado (Toren, 1993, 2003,2010, 2012; Ingold, 1991,1993,2002; Lave, 1988,1996, 2011). Há ainda a Antropologia da Criança, cuja abordagem tem pressupostos específicos (Cohn, 2000 e 2005; Pires, 2010). Os desdobramentos dessas abordagens resultam assim em debates sobre a possibilidade de estudos etnográficos com crianças e/ou com participação das crianças, como mostraram Levine, 2007 e Milstein, 2010 e podem ser encontrados em Pires, 2010, Cohn, 2000, Hardman, 2001 e Silva, 2016, Borges e Kaiser, 2011. 
"Tomar cuidado com o que eu falo": ser criança na escola, ficar e brincar em casa

explicativas a respeito do que queriam mostrar, de modo talvez a evitar equívocos e direcionar nossa compreensão do que desenhou para aquilo que ele conhecia.

Diante do envolvimento das crianças na participação dessa atividade, propusemos a construção conjunta de um "livrinho" intitulado Minha história de vida (Alcântara, 2012). Um dos objetivos dos desenhos é contar "história de vida", estratégia narrativa utilizada desde a educação infantil, pois permite o reconhecimento da criança como sujeito social da própria história no mundo. Esse instrumento possibilita maior aproximação com as crianças, buscando compreender como se significam em interação conosco. Nosso objetivo era compreender a forma de vida cotidiana em suas relações entre os adultos no bairro, com seus familiares, com a escola e com o trabalho dos adultos. A história de vida foi construída conjuntamente, reunindo a pesquisadora, a professora e 20 crianças. Propusemos um roteiro para essa construção, feita em duas etapas, de uma hora e trinta minutos cada, em datas diferentes na sala de aula. Além das perguntas, dúvidas, orientações e conversas entre nós durante essa construção, a crianças puderam escrever ou desenhar, segundo sua preferência. Apresentamos, então, neste artigo, dados etnográficos coconstruídos com as crianças (Alderson, 2000) $)^{5}$ advindos de diferentes formas expressivas, tentando não separá-las entre a oralidade, a escrita e o desenho. Com isso, a ideia é diluir as oposições comuns entre denominar e mostrar, dizer e figurar, imitar e significar, olhar e ver (Foucault, 2006, p. 251).

Como pretendemos mostrar, e em virtude da familiaridade do tema, nossas conversas com as crianças, seus desenhos e seus escritos foram incorporados tanto por seus significados autoevidentes, para nós e para elas, pois todos sabemos do que se trata, mesmo de modo e em posições diferentes. E foram essas posições diferentes que introduziam novos referentes no próprio processo de interlocução entre nós. Uma vez que nem o que era ouvido, falado, escrito e visualizado em desenhos eram tomados em seu aparente realismo, imediato, a interpretação e compreensão sobre as formas de vida ligadas ao trabalho fronteiriço só puderam ser referidas

\footnotetext{
${ }^{5}$ Como sugeriu essa autora, o fato de crianças serem envolvidas em pesquisas elaboradas por adultos implica muitas vezes que elas aprendam cada vez mais a planejar perguntas, coletar, analisar ou relatar dados.
} 


\section{Regina Coeli Machado e Silva \\ Marisa Elizabete Cassaro Godoy}

às circunstâncias do momento em que elas foram construídas. Isto é, durante as conversas com cada uma das crianças. Foi no processo de coconstrução que aos poucos foram sendo revelados os contrastes entre o nosso autoentendimentos sobre as atividades de transporte de mercadorias e o entendimento das crianças sobre isso: no momento da conversa, interrogando a respeito desses temas. Mesmo que nos parecessem autoevidentes, nos desenhos esse entendimento foi sendo co-construído reflexivamente por meio de especificações, assimilações, identificações e distinções de outros contextos contrastantes como tentaremos mostrar. As próprias legendas, escritas pelas crianças, tornaram-se a objetivação desse contrastes, por meio desse entendimento diferenciado.

Resta mencionar que o recurso aos desenhos das crianças, importante para esta etnografia, não se limita aos que nós, crianças e pesquisadores, vemos e ao que nós, pesquisadores, deduzimos em função da nossa familiaridade com o assunto. Os desenhos foram um meio de comunicar o saber das crianças pela participação ativa delas, tanto no contexto onde vivem além da escola quanto no momento em que eles estavam sendo construídos, em situação de presença, delas e nossa. Os desenhos não foram utilizados como técnicas projetivas capazes de oferecer a percepção de mundo do ponto de vista das crianças, não foram utilizados como representações miméticas e nem como documentos identificados como fontes primárias a serem interpretados a posteriori. Tal como os diálogos, a conversa e os gestos corporais, os desenhos emergiram como formas expressivas na relação e na interação entre nós. Os pressupostos abstratos dessa concepção vêm de uma abordagem consistente com a ontologia social da cognição que concebe a oralidade, os desenhos, a escrita e outras formas expressivas como práticas sociais e as crianças como interlocutoras de um processo de aprendizagem em suas relações com o mundo adulto, como afirma Cristina Toren (1993). A infância não é uma etapa isolada da vida adulta, mas se constitui como espaço de intersubjetividades, obtendo conhecimento sobre o mundo por meio de relações sociais que as crianças estabelecem como membros da comunidade.

\section{Ter cuidado com o que fala: o sigilo como um dos modos relacionais}


"Tomar cuidado com o que eu falo": ser criança na escola, ficar e brincar em casa

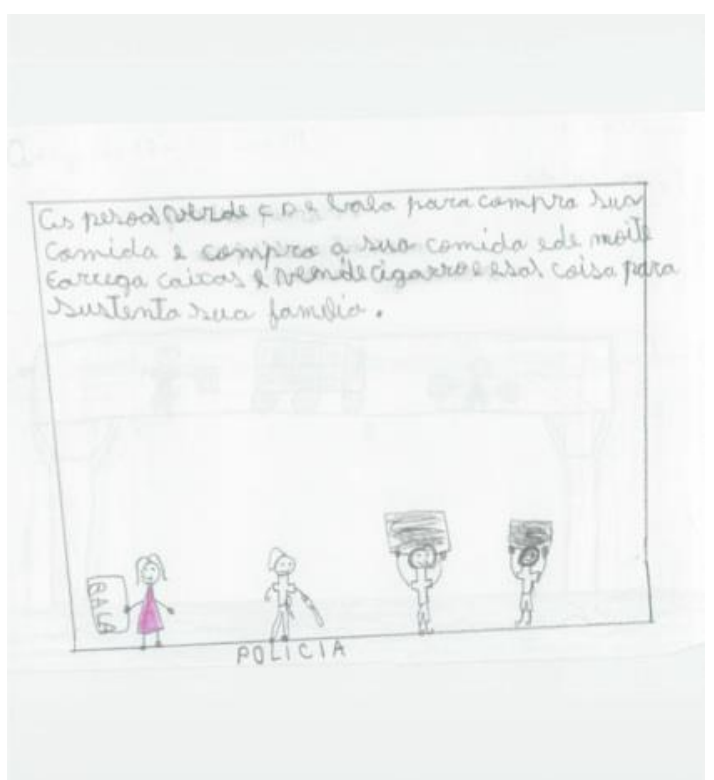

Fig. 1 - O que é a fronteira.

Produzido por Olívia com 11 anos.

Fig. $2 \mathrm{O}$ que veem na Ponte da Amizade

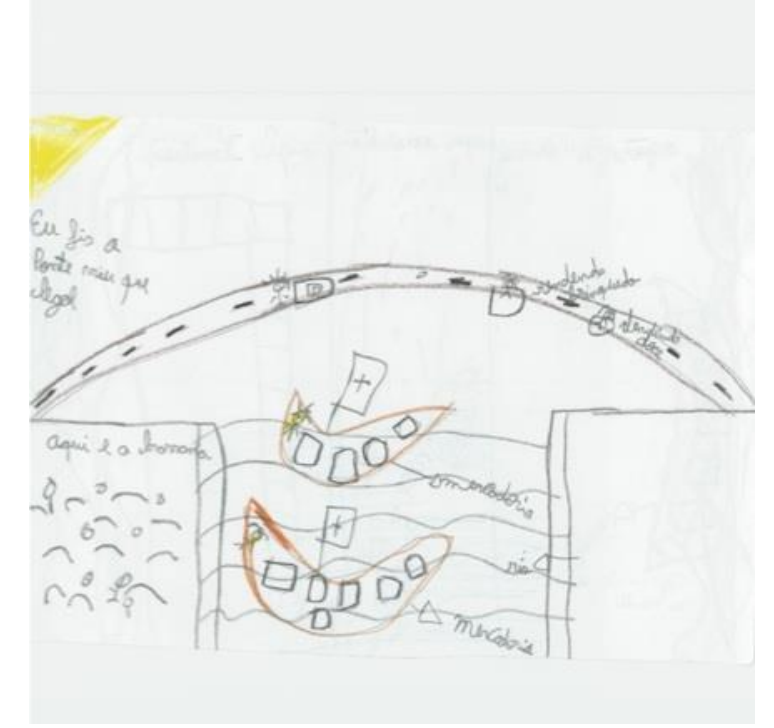

Produzido por Luciano com 11 anos.

Iniciamos expondo o autoentendimento das crianças com esses dois desenhos. Com nomes fictícios, o primeiro é de Olívia, uma menina de 12 


\section{Regina Coeli Machado e Silva \\ Marisa Elizabete Cassaro Godoy}

anos. O segundo é de Luciano, com 11 anos de idade. Como acabamos de mencionar, os desenhos foram construídos na escola, mas o significado do compartilhar os temas contidos neles excede esse espaço físico porque sinalizam a participação, a escuta e as observações que nos implicam, igualmente, como moradoras da mesma cidade, apesar de nossas inserções e pontos de vista diferentes.

Os desenhos foram um meio de entrar em diálogo, mas também são respostas parciais a um modo de existência marcado por reticências e silêncios. O silêncio aqui é entendido como um intervalo impreciso para as sutis modulações de comunicação entre nós, e seu conteúdo adquire um sentido de cumplicidade que compreendemos rapidamente. Compreendemos porque esse intervalo diz respeito ao sigilo que instala o limite entre pertencer ao local, ao bairro e à cidade de Foz do Iguaçu, ou ser visto como distante ou extralocal, estranho ${ }^{6}$. O significado desse sigilo é semelhante à exposição da carta roubada, um conto de Edgar Alan Poe, colocada em um local de tal modo evidente que se tornou quase impossível percebê-la. Assim, para nós, pesquisadores, e para nossos interlocutores, as crianças, o primeiro desenho, acompanhado de sua legenda, dispensaria qualquer acréscimo para ser entendido. É a visualização da experiência de um cotidiano visto por nós, mas vivido e conhecido pelas crianças. Quando Olívia vai à escola ou sai de casa em companhia dos avós - aqueles que ela encontra estão imersos em seus afazeres cotidianos. Na legenda, ela escreve: "as pessoas vendem CD e bala para comprar sua comida e compra a sua comida". Essa verbalização do cotidiano detalha um modo de fazer em relação com os outros, especialmente a família, mas exclui dessa narrativa a presença do policial. Durante a conversa ela diz "o pai carrega caixa; a mãe é recicladora e passa mercadoria; o irmão e o tio trabalham no rádio (como "olheiros"). A figura do policial é visualizada no desenho,

${ }^{6}$ Simmel (1906) estudou a significação sociológica do segredo como modo de realização, medida prática e capacidade ou não de grupos ou pessoas guardá-lo. Segundo ele, do contraste entre esconder e descobrir brotam o matiz e o destino das relações mútuas entre os homens. O tema do segredo é um tópico antropológico paradigmático pois é uma prática que envolve fluxos de conhecimento e está intimamente relacionado ao risco (Jones, 2014). Nesse contexto etnográfico, parece que o risco envolvido no transporte de mercadorias considerado ilegal engendra o sigilo como estratégia de gerenciar as relações dessa atividade. 
"Tomar cuidado com o que eu falo": ser criança na escola, ficar e brincar em casa

mas identificada fora do enquadramento dos limites gráficos, não como uma pessoa fazendo algo ao lado ou junto uma das outras, mas como uma presença que não pertence ao lugar, externa: a polícia como corporificação da instituição de vigilância oficial.

O mesmo fazer está presente no desenho de Luciano: pessoas vendendo doces e brinquedos. Se no desenho de Olívia esses fazeres estão presentes em um lugar indeterminado justamente pelo excesso da presença, no de Luciano, eles estão ocorrendo na passarela da ponte entre os dois países. Em nenhum lugar Luciano identificou o lado direito do desenho como sendo Ciudad del Este/Paraguai e o esquerdo Foz do Iguaçu/Brasil. O lado esquerdo é precisamente o que lhes é familiar, a parte do bairro onde vivem, conhecida como "barranca". Essa identificação é desnecessária, pois todos nós, moradores da cidade, conhecemos o local, como também inútil é a indicação de que os barcos sob a ponte carregam grandes caixas com mercadorias, de que o lado direito de onde sai a ponte é um "vazio", e o lado esquerdo, enfatizado com a descrição "aqui é a barranca", é povoado por pessoas que mal enxergamos, quase ocultas, mas em diferentes posições e inseridas em movimentos de arbustos que Luciano mimetizou como ondas.

Os desenhos sintetizam o modo de existência dos moradores da fronteira, particularmente as crianças moradoras do Jardim Jupira, um local estigmatizado para os moradores de outros locais da cidade, e por eles considerado interdito. Não só para as instituições de controle alfandegário e outros moradores da cidade, esse modo de existência é caracterizado como práticas ilegais em condição fronteiriça, como o contrabando e o descaminho. Por isso, nos desenhos das crianças, está a presença inescapável da polícia, o transporte intenso de mercadorias passando pelo rio e as atividades de comércio sobre a ponte que liga os dois países. Contudo, esse mesmo mundo visível e incontroverso está envolto em ambiguidades, perceptíveis, justamente, nas reticências e nos silêncios de uma experiência cotidiana dessas crianças, comunicáveis, paradoxalmente, no sigilo, figura que separa os que vivem dessas práticas ilegais daqueles que não o fazem.

O que aqui apresentamos é, portanto, o autoentendimento dessas crianças que podem fazer do sigilo um modo de relação e interlocução conosco. Se seus pais podem ser qualificados como contrabandistas pela lei nacional que assim os insere nos interesses da economia nacional, tal 


\author{
Regina Coeli Machado e Silva \\ Marisa Elizabete Cassaro Godoy
}

criminalização deixa na sombra o caráter parcial e transitivo dessas ações. Se usando as lógicas dos direitos poderíamos dizer que os adultos são cidadãos em conflito com a lei, por outro lado, deixam de ser cidadãos sob muitos aspectos, tornando-se alvo de arbitrariedade em suas relações com diferentes agentes, legais e ilegais. A instrumentalização dessa "realidade", como ameaça às segurança pública e nacional e o modo pelo qual essa mesma "realidade" é vivida como formas de controle e violência exercida no interior do bairro tanto por agentes legais quanto por moradores, tem como resultado o cerceamento da mobilidade das crianças e um permanente controle de todos pela relação "olhar e ser olhado" que inibe e constrange a voz das crianças quando estão fora do bairro. Buscamos privilegiar o ponto de vista das crianças, compreendendo que ouvir é um processo interpretativo e que as crianças podem se fazer ouvir de muitas maneiras, por meio da linguagem escrita e falada, gestos e desenhos, como mencionamos acima.

O imperativo dado às crianças de "ter cuidado com o que fala" tornou, assim, parte de um diálogo feito por reticências e silêncios. Esse cerceamento da voz das crianças advém do sigilo como uma figura a marcar um limite entre dois modos de existência separados, mesmo de modo imperfeito: os que vivem das atividades ilegais daqueles que não a vivem. Essa "separação" se desdobra no distanciamento simbólico do bairro, advindo dos preconceitos dos moradores da cidade que o associam com criminalidade e violência. Esse é o reverso do próprio modo de existência do bairro que assim se fecha em sua defesa, como antes mencionado.

\title{
Ser criança na escola, ficar e brincar em casa
}

A escola onde encontramos as crianças está localizada no bairro Jardim Jupira, cuja origem se dá com a atividade comercial de algumas famílias sírio-libanesas chegadas a Foz do Iguaçu em 1953 como mascates (Zamberlan, 2007). Com a construção da Ponte da Amizade, em 1965, e o loteamento da área pertencente a Carlos Sottomaior, criou-se aí uma estrutura voltada para a exportação para o Paraguai. Após a assinatura do Tratado Comercial do Mercosul em 1995, o comércio atacadista entrou em crise, acentuando-se mais a partir do ano 2000, quando as autoridades alfandegárias brasileiras estabeleceram quotas menores para pessoas físicas 
"Tomar cuidado com o que eu falo": ser criança na escola, ficar e brincar em casa

do Brasil (U\$300) e quotas mais elevadas para exportação por atacado (U\$2000). Com a crise financeira brasileira, iniciada em 1995, os empresários da exportação transferiram seus escritórios para a cidade de Assunção, no Paraguai, afetando o desenvolvimento de Foz do Iguaçu e os trabalhadores. Os bairros próximos à Ponte da Amizade, que eram o centro das empresas exportadoras de Foz do Iguaçu, tornaram-se, a partir de 1996, espaços fantasmas de empresas, galpões fechados e poucas lojas que insistem em sobreviver, principalmente as que comercializam artigos de cama, mesa, banho e utilidades domésticas. A palavra Jupira é de origem indígena e significa "qualquer planta que alimenta". Por analogia, pode-se juntar esse significado ao fato de os moradores do bairro serem "alimentados" por uma multiplicidade de atividades exercidas nesta fronteira.

Parte desse bairro está em áreas verdes que foram ocupadas irregularmente, ao longo do tempo, no município. Essa comunidade caracteriza-se por duas realidades totalmente distintas e sem relação entre si. Uma delas é a estrutura comercial construída para exportação e importação de produtos, conhecida como a área de exportação que, após a criação do tratado do Mercosul, em 1995, está quase totalmente desativada. A outra realidade são as ocupações precárias localizadas em quatro espaços distintos definidos assim pelos moradores: Jupira baixo, Pedreira e Rua Vicente de Carvalho, Jegue Sentado ou Rua Mário de Andrade, e Boca do Mato ou Rua Gonçalves Dias. A ocupação das áreas verdes no bairro Jardim Jupira iniciou a partir do final da década de 1960 e, de forma abrupta, cresceu nas décadas seguintes, com a chegada de trabalhadores que se deslocaram até Foz do Iguaçu em busca de novas oportunidades ou que viviam por meio de atividades pouco remuneradas ou sem amparo da legislação trabalhista.

As crianças do bairro estão matriculadas na Escola Municipal Ponte da Amizade, mantida pela Prefeitura Municipal de Foz do Iguaçu. Foi fundada e inaugurada em 25 de agosto de 1968 e municipalizada em dezembro de 1992 pela resolução $n^{0}$ 5133/92. A escola possui, atualmente, 7 salas de aula e funciona no horário matutino e vespertino. Tem 350 alunos, a maioria residente nas ocupações do Jardim Jupira, 20 professores especialistas, 2 cozinheiras e 4 auxiliares de serviços gerais

O Projeto Político Pedagógico elaborado em 2012 caracteriza a população como "tendo nível socioeconômico baixo com predominância de 


\section{Regina Coeli Machado e Silva \\ Marisa Elizabete Cassaro Godoy}

trabalhadores da classe autônoma: pedreiros, mecânicos, diaristas, costureiras, ou de empregados instáveis ('laranjas')". A expressão "laranjas" é usada nesse documento para se referir às pessoas que transportam mercadorias do Paraguai para o Brasil.

Os eventos que compõem a história da escola ${ }^{7}$, são inseparáveis de todo o movimento social e econômico do bairro. Do mesmo modo, o seu funcionamento cotidiano. Os alunos maiores, de terceiro ao quinto ano, estudam no período matutino, porque podem dirigir-se até a escola sozinhos. Os menores, de pré-escolar, classe especial, primeiro e segundo ano, estudam no período vespertino, porque necessitam de acompanhantes para organizar a rotina diária e levá-los até a escola. Segundo a diretora, essa foi a estratégia adotada para diminuir a evasão escolar. Os pais e/ou responsáveis trabalham nos períodos da tarde e da noite. Quando a escola atendia os menores no período da manhã, o número de faltosos tornou-se insustentável; as crianças constantemente faltavam às aulas porque os pais estavam dormindo, descansando do trabalho, na maioria das vezes, noturno. O trabalho dos pais e/ou responsáveis começa a partir das 16 horas, tornando o trânsito no bairro mais intenso, devido à saída de vans, carros e camionetes com mercadorias vindas do Paraguai.

A mesma estratégia é usada para as visitas domiciliares por técnicos de serviços públicos. Quando necessárias, as visitas às famílias do bairro são realizadas a partir das dez horas da manhã e até as 14 ou 15 horas. Como se vê, a escola tornou-se parte integrante do cotidiano da grande parte das pessoas do Jardim Jupira.

Nas primeiras visitas à escola, percebemos, em várias crianças, um olhar atento, silencioso e, em algumas, um olhar desconfiado. Aos convites de falarem sobre elas, suas vidas e suas famílias, apenas olhavam. Por

7 A equipe escolar procura adequar-se às necessidades dessas crianças para o controle da evasão escolar, segundo as normas previstas pelo IDEB (Índice de Desenvolvimento e Educação Básica). O IDEB é um indicador de qualidade educacional que combina informações de desempenho em exames padronizados (Prova Brasil ou Saeb) - obtido pelos estudantes ao final das etapas de ensino (4. $\stackrel{\mathrm{a}}{\mathrm{e}}$ 8. ${ }^{a}$ séries do ensino fundamental e 3. ${ }^{a}$ série do ensino médio - com informações sobre rendimento escolar (aprovação). A média nacional do IDEB, registrada em 2009 para os anos finais (6.ำ ao 9.․ano) do ensino fundamental, cresceu de 4,0 para 4,1 em 2011 e 4,2 em 2013. (Disponível em: http://portal.inep.gov.br/. Acesso em 22 set. 2014) 
"Tomar cuidado com o que eu falo": ser criança na escola, ficar e brincar em casa

várias semanas, trocavam olhares entre elas mas nenhuma palavra conosco. Como vimos, esses silêncios reticentes traçam os limites entre dois contextos e dois modos de existência: o contexto delas, estigmatizado e fechado, e o nosso, institucional, da educação e do controle escolar; elas, as crianças, e nós, os adultos, pesquisadores, professores da escola e gestores.

A escola está localizada em uma avenida asfaltada, diferente da apreciação das crianças em relação às ruas de seu bairro. Em uma das atividades, quando estávamos em sala de aula após o recreio, a professora propôs atividade de leitura e de interpretação de uma poesia sobre a "rua". Depois, elaborou perguntas sobre a rua onde cada criança residia e pediulhes que contassem algum acontecimento julgado importante. Luciano (nome fictício, 11 anos) escreveu: "Eu não gosto da minha rua. Tem muita poeira quando os carros passam por lá. Moro bem perto da barranca do rio". Francisco (nome fictício,12 anos) solicitou a presença da pesquisadora na sua carteira e com voz baixa relatou: "Minha mãe não deixa eu brincar na rua". Segundo o relato da professora, quando a previsão do tempo é de chuva, muitas crianças faltam, porque moram distante para virem a pé, além de existirem no trajeto subidas íngremes em meio a pedras, condição que dificulta a caminhada até a escola. Quando surpreendidos pela chuva, muitos ficam resfriados e doentes, justificativa para as faltas às aulas por quatro a cinco dias seguidos.

Em vários momentos de recreio com as crianças, nas conversas informais, é que elas falavam das relações familiares, especialmente as meninas. Elas são divertidas, curiosas e gostam de ser ouvidas. Marília (nome fictício, 11 anos) mostrava-nos feliz a coreografia de uma música que aprendeu enquanto cantava com outra colega. Após os aplausos, iniciou-se uma conversa: Além de cantar e dançar, o que mais você faz em sua casa? "Ajudo varrer, lavar louça e cuidar de minha irmã. A minha mãe fica em casa com a gente". Sua mãe não trabalha fora? "Não ela fica com a gente, só meu pai trabalha". Olhou demoradamente para a colega e a troca de olhares demonstrava claramente que a colega sabia bem o que ela estava dizendo sem dizer. Ficaram em silêncio.

Em virtude das atividades no bairro, como medidas de cuidado e de proteção aos filhos, a maior parte das mães permanece em casa, atentas. As crianças permanecem dentro das casas, brincando no quintal ou jogando videogame, estudando ou auxiliando as mães nas tarefas domésticas. Alguns relatam que a mãe faz cobranças quanto às atividades da escola. Se 


\section{Regina Coeli Machado e Silva \\ Marisa Elizabete Cassaro Godoy}

essas não forem executadas, há repreensões: a "mãe xinga", "eu apanho"; "pede que eu faça de novo"; "não posso assistir TV"; "não posso sair, fico de castigo".

Quando pedimos às crianças que desenhassem o uso do tempo em quatro momentos de um dia comum a ideia foi que as crianças pudessem se expressar a respeito de seu cotidiano. A escola apareceu como um dos principais momentos do dia, ocupando o $1^{\underline{0}}$ e $2^{\underline{o}}$ lugar de importância, seguido do horário do almoço com a família e dos momentos de lazer com os colegas em suas casas. Na figura 4, produzida por Carolina (nome fictício,10 anos), aparece um $3^{-}$momento em que a mãe espera seu retorno da escola. A figura 5, produzida por Lúcia (nome fictício,10 anos), expressa dois momentos particulares: auxiliando na separação do lixo - é filha de recicladores - e as viagens que faz para tratamento de saúde na capital, Curitiba.

Figura 3 - Os quatro momentos de um dia

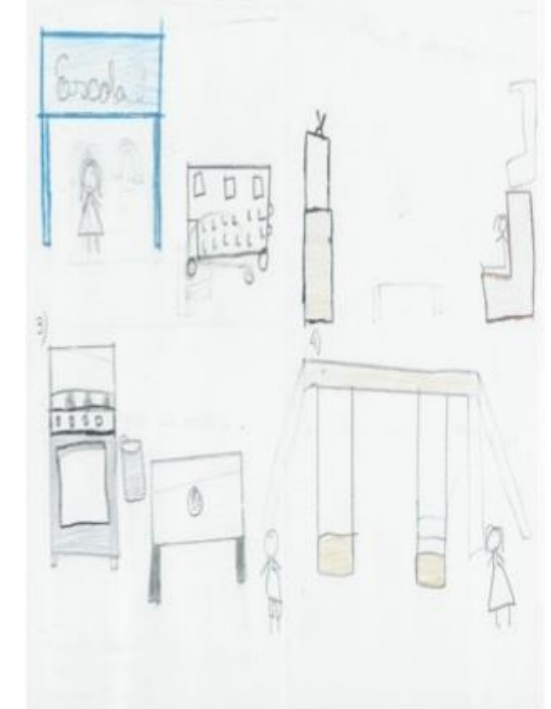

Produzido por Mariana com 11 anos 
"Tomar cuidado com o que eu falo": ser criança na escola, ficar e brincar em casa

Figura 4 - Os quatro momentos de um dia

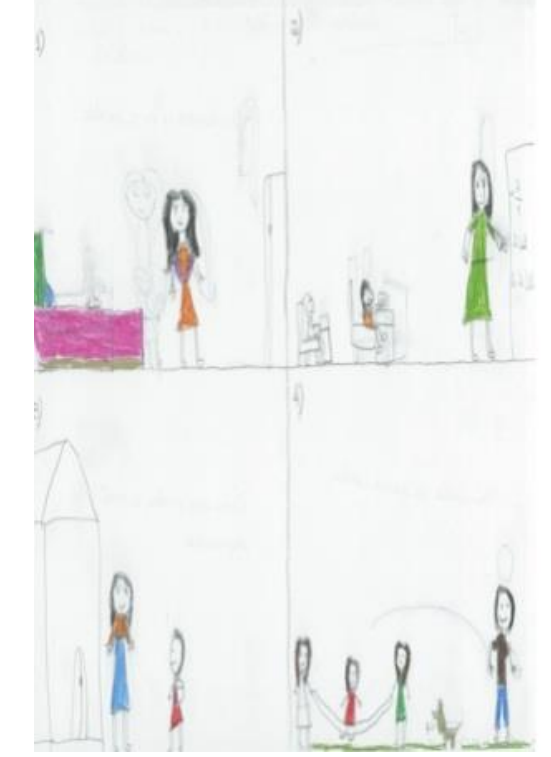

Produzido por Carolina com 10 anos

Figura 5 - Os quatro momentos de um dia

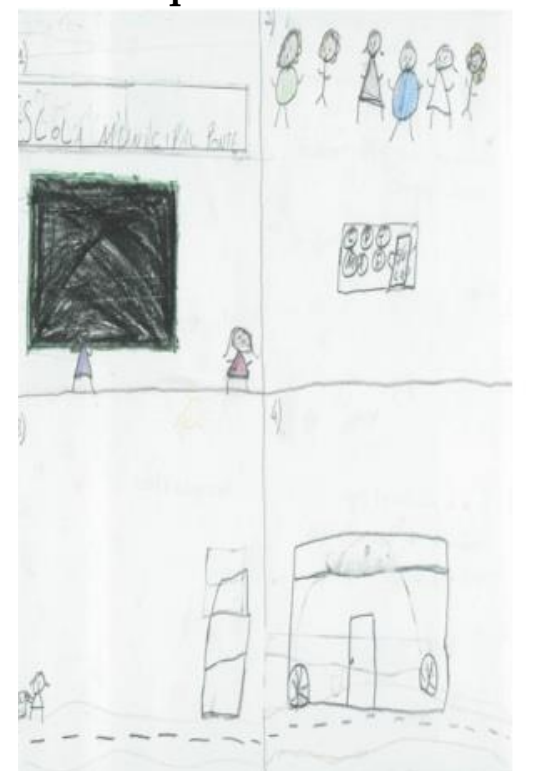

Produzido por Lúcia com 10 anos.

Para os alunos, a escola é importante porque "serve para ensinar", "aprender coisas novas" e "estudar", principalmente quando é referenciada 


\section{Regina Coeli Machado e Silva \\ Marisa Elizabete Cassaro Godoy}

de forma positiva pelos familiares. Quando a escola não é um tema na família, esta não é referenciada, não ocupa um lugar de importância na vida da criança e passa a ser vista como necessidade de atender a um interesse ou ao cumprimento de uma exigência, por exemplo, para receber o Bolsa Família ${ }^{8}$.

Outro momento em que se pôde ter contato com a realidade social do bairro em questão foi na observação de diálogos entre a professora e alguns alunos. Os relatos a seguir são fragmentos de vários momentos presenciados em sala de aula, quando interagimos mais com as crianças. Nas conversas paralelas emergem as percepções sobre as atividades e o movimento do bairro. Nelas também percebemos que elas são atentas e acompanham o movimento do bairro onde moram, como também observamos que há meninos que já exercem o papel de auxiliares no carregamento das mercadorias vindas do Paraguai.

Em brincadeiras, referem-se às armas, ou calibre delas, por meio de chistes no cotidiano da sala de aula. Quando a professora queixava-se da falta de atividades nos cadernos ou do excesso de conversa entre eles, referiu-se a um dos alunos: Se Dario (9 anos) não trabalhar, vai retornar para a outra sala de quinto ano. Um outro garoto esperto, usando um boné, a quem chamarei de Diego (12 anos) disse: "Eu dou $\mathrm{R} \$$ 0,15 para você ficar e comprar balinha". Armando (12 anos) respondeu com olhar maroto: "Balinha de 38 ou 39". Sorriu, dirigindo um olhar de cumplicidade para Diego e para Dario. A balinha refere-se à munição de armas de fogo, com certeza conhecidas pelas crianças ao fazer parte do cotidiano do bairro onde residem, seja através de contato direto ou de conversas. Armas e munições apreendidas no bairro são manchetes recorrentes nos jornais locais sobre o bairro Jardim Jupira ${ }^{9}$.

\footnotetext{
${ }^{8}$ O Programa Bolsa Família foi criado em 2003 e regulado pela Lei Federal $\mathrm{n}^{\mathrm{o}}$ 10.836, de 9 de janeiro de 2004 -regulamentado pelo Decreto $n^{\circ}$ 5.209, de 17 de setembro de 2004. Está inserido em uma política macroeconômica que visa à ampliação de políticas direcionados à grande parte da população que vivia abaixo da linha da pobreza ou em um nível elementar de sobrevivência e consumo. Tratase não apenas da realização de políticas compensatórias e de baixa distribuição de renda, ou das políticas de descriminação positiva, mas do acesso diferenciado e intenso ao crédito para a casa própria e a bens de consumo, a programas de acesso à energia etc

${ }^{9}$ http://www.jtribunapopular.com.br
} 
"Tomar cuidado com o que eu falo": ser criança na escola, ficar e brincar em casa

A relação inseparável entre a fronteira e o trabalho de transportar mercadorias apareceu durante a participação em uma das aulas, transcrita das anotações do diário de campo ${ }^{10}$. Luciano (11 anos) pediu ajuda a uma das pesquisadoras na interpretação de texto. Ao lado dele, perguntei: “Ontem você não veio à aula, o que aconteceu?"

Luciano (11 anos) "Estava barro ainda, moro bem perto da barranca. Meu tio já foi lancheiro" (piloto da lancha). "Eu já fui com ele na lancha para o Paraguai. Não gosto de nada lá". Diego (12 anos) completou: "Ali a maioria é chiru (Paraguaio) tem pouco brasileiro lá".

Havia, nos olhos de Luciano (11 anos), prazer ao me relatar a experiência de atravessar o rio Paraná. Enquanto isso, Diego (12 anos) nos olhava demoradamente. Ele se veste com roupas típicas da sua idade, um boné de lado, corrente grossa no pescoço. Não falava comigo, observandome com um olhar desconfiado. Percebe-se, claramente, uma tática para manter o distanciamento ao mudar o tema da conversa, uma vez que Luciano falava do seu trabalho com o tio. Diego declara que a maioria é "chiru", uma maneira pejorativa de referir-se ao paraguaio na fronteira. Começou a falar com o colega, algumas palavras em guarani, as quais não pude compreender, e começou a rir. Luciano pareceu entender bem o que ouviu. Nas entrelinhas da conversa, penso ter entendido a mensagem a partir de seu olhar esperto e inteligente: Neste local não se fala português e só tem paraguaio. Não queira entender esse assunto, é muito particular e você não fala guarani!

Continuei na sala, caminhando até o final da fila, quando Francisco (12 anos) muito quieto e atento à conversa de Diego, continuou:

Francisco (12 anos): "A lancha trabalha desde cedo até 9 horas da noite. Eles trazem armas e escondem no mato, se a polícia chegar de lancha, leva tudo. Meu pai já tirou foto da polícia passando perto de helicóptero. Meu pai ajudou a esconder as caixas lá em casa, para a polícia não pegar. Tinha caixas de pendrive, notebook e Playstation II. Aí depois eles dividiram em 9. Meu pai vendeu tudo para um rapaz que tem loja. Outro dia, ajudou a esconder caixas de jaquetas, daquelas com touca, bem bonitas, como

\footnotetext{
${ }^{10}$ As anotações de diário de campo foram feitas por Marisa Godoy. A escrita em primeira pessoa expressa esta parte da construção progressiva dos dados etnográficos.
} 


\section{Regina Coeli Machado e Silva \\ Marisa Elizabete Cassaro Godoy}

aquela ali (apontou a jaqueta da colega pendurada na cadeira) depois, meu pai vendeu a parte dele do que foi repartido. Eles dividiram entre eles".

Mesmo que as crianças permaneçam dentro de casa, estão acompanhando o movimento do trabalho realizado e ouvindo os adultos. Os pais podem até possuir uma atividade remunerada e regularizada em um comércio, mas podem também ter outras atividades ligadas ao trabalho com mercadorias realizado no bairro. Esconder armas para não serem apreendidas, guardar caixas carregadas de objetos para não serem tomadas pela polícia é, para as crianças e suas famílias, um trabalho, ou seja, uma forma de ganhar dinheiro na fronteira. Tal percepção foi compartilhada por todas as crianças com as quais convivemos na sala de aula. Eles não são os muambeiros. Residem lá e estão guardando, protegendo, cedendo a casa como depósito, em troca de uma taxa de serviço de guarda-volumes. Não veem nada de errado do ponto de vista moral. Os pais estão trabalhando, cuidando da manutenção de seus filhos e da esposa. São carregadores ou, na linguagem dos moradores e das crianças, "puxadores" ou "passadores" de mercadorias.

Alguns alunos, no entanto, já trabalham na barranca do rio ajudando a "puxar" muamba do rio para as margens, outros vendem lanches, bolo e café para os que estão trabalhando. Alguns fazem a função de "olheiros". Um aluno dormiu na sala de aula e o colega comentou: "Deixa ele dormir, trabalhou a noite toda como olheiro, professora, não aguentou". A professora depois comentou que as crianças passam por experiências no dia a dia que "não imaginamos, não sabemos o que fazer e dizer". Como o bairro Jardim Jupira está localizado próximo às margens do rio Paraná, seus moradores recebem e armazenam mercadorias vindas através do carregamento de "muamba" da Ponte da Amizade, ou do rio, por uma espécie de cais na barranca do lado brasileiro. $\mathrm{O}$ trabalho, a cargo dos "laranjas", como são conhecidas as pessoas que transportam as mercadorias, é descrito no livro de (Cardin, 2011) no livro Laranjas e Sacoleiros na Tríplice Fronteira:

Vou direto para uma favela nas proximidades do Rio Paraná onde tem, como se fosse um cais, uma espécie de porto para o atraque das embarcações que vêm do Paraguai com contrabando... A mercadoria que atravessa é colocada no porta-malas de um carro, de preferência de luxo para não 
"Tomar cuidado com o que eu falo": ser criança na escola, ficar e brincar em casa

levantar suspeita. Tempra, Vectra, Maréa são carros alienados que servem para rodar no máximo um ano e meio, até dar busca e apreensão. [...] a mercadoria depois vai para um hotel nas redondezas e aí outras pessoas entram em ação levando até seu destino... [...] um traz o carro para trabalhar, outro faz a segurança com rádio amador, tudo certo, afirma o interlocutor (CARDIN, 2011 p. 86).

O trabalho descrito por Cardin esclarece uma organização em rede, com vocabulário próprio. Nas nossas conversas, as crianças e os adolescentes mencionaram que alguns auxiliam na retirada das mercadorias da lancha ou do barco até o veículo, outros organizam a carga de um veículo para outro, ou mesmo ficam em diferentes pontos do bairro com o rádio comunicador para dar informações sobre a presença ou não de policiais.

Sob o olhar da moralidade infantil, ou seja, o que as crianças na faixa de 8 a 12 anos consideram ou percebem como certo ou errado nas suas experiências de vida, há vários desenhos além dos dois apresentados no início deste texto. Entre as figuras abaixo, está a do desenho de uma camionete com mercadoria em cuja legenda se lê: "jogando caixa pela ponte e depois eles vão carrega no carro e vai desenhar o carro com caixa. E eles corre muito quando a polícia entra na Vila ${ }^{11}$. E eles se arrisca muito, mas é por uma causa, para sustentar a família". Logo abaixo desse desenho há outro, em que as crianças estão vendendo CDs, brinquedos e doces. "Eles fazem isso para sustentar a família, pra ter do bom e do melhor, pra comprar roupas, comidas etc.

Fig. 6 - O que veem na Ponte da Amizade

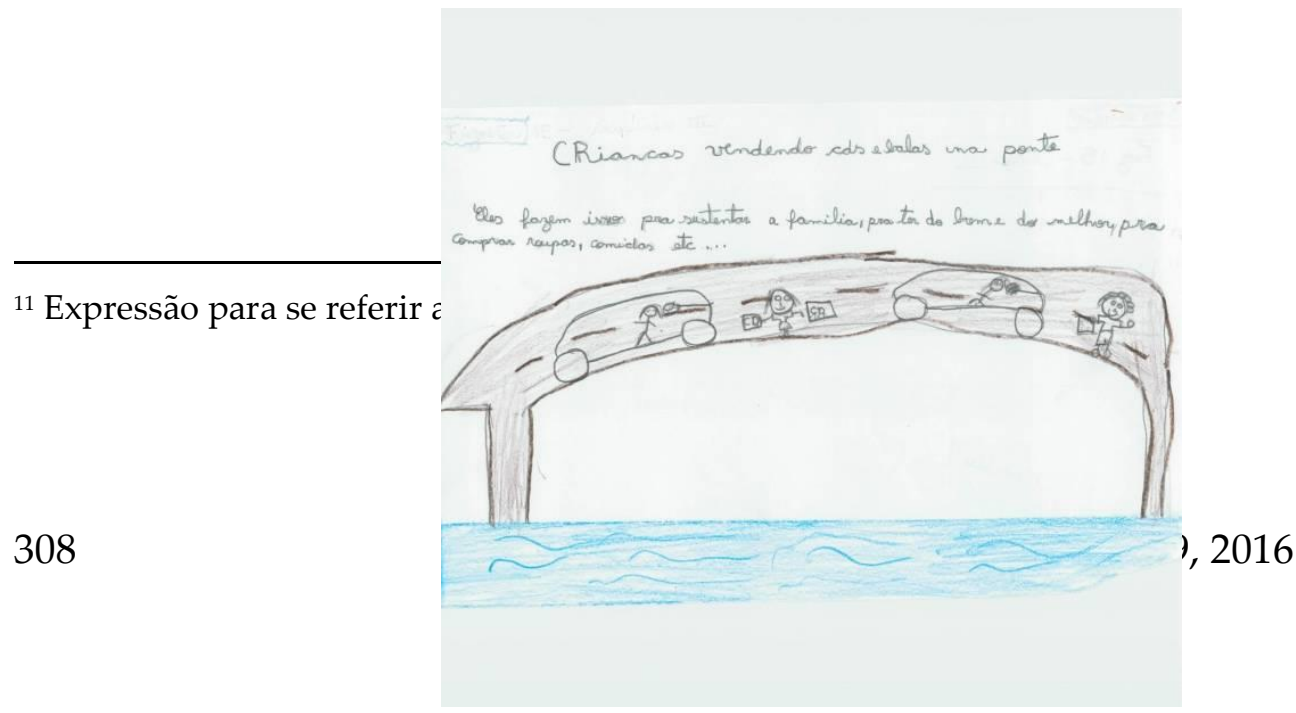


Regina Coeli Machado e Silva Marisa Elizabete Cassaro Godoy

Produzido por Luciano com 11 anos. 
"Tomar cuidado com o que eu falo": ser criança na escola, ficar e brincar em casa

Fig. 7 - O que veem

na Ponte da Amizade

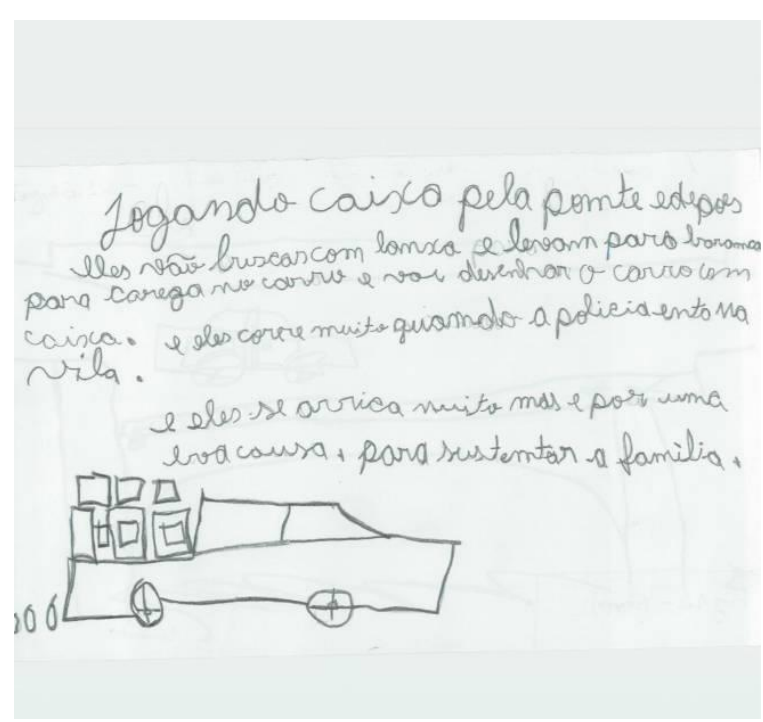

Produzido por Luciano com 11 anos

Ajudar os pais no trabalho, mesmo que esteja ligado ao carregamento de mercadorias vindas do comércio paraguaio, é recorrente. Para as crianças, transportar mercadorias do Paraguai para o Brasil não é percebido como um trabalho ilegal. Para elas, os muambeiros são os patrões, quem os encarrega de trazer as mercadorias. Os patrões são vistos como suspeitos de estarem agindo ilegalmente, vistos como um "outro", estranho no bairro, e fazendo dele uma passagem necessária para as mercadorias que vieram do Paraguai. Esses patrões provocam medo nas crianças pelo movimento intenso e acelerado dos veículos que passam por elas. Para as crianças, os moradores estão apenas trabalhando para que as mercadorias, eletrônicos, cigarros, brinquedos e "bugigangas", cheguem ao seu destino ${ }^{12}$, isto é, a todo o Brasil.

${ }_{12}$ Comprovam-se esses dados com a divulgação dos volumes apreendidos pela Delegacia da Receita Federal de Foz do Iguaçu no ano de 2014, 5\% maior que o registrado no ano anterior. Esse valor compreende toda a jurisdição da Delegacia, abrangendo toda a fronteira do Paraná com o Paraguai. Cigarros, eletrônicos e veículos representam mais de $80 \%$ das apreensões. A comercialização de cigarros, atividade citada por várias crianças, aumentou $99 \%$ comparado ao ano anterior; foram 42 milhões de maços apreendidos, enquanto os eletrônicos diminuíram 34\%. 


\author{
Regina Coeli Machado e Silva \\ Marisa Elizabete Cassaro Godoy
}

\begin{abstract}
Observamos que as crianças utilizam um discurso comum, orientado e falado pelos adultos, de que aqueles que estão carregando as mercadorias o fazem para a sobrevivência, para comprar comida, para o sustento da família, por vezes auxiliados pelas crianças, sempre com os olhos atentos à vinda da polícia, frequente no bairro onde vivem. Esse discurso é utilizado como uma espécie de escudo para justificar, de forma simplista, um modo de existência que é parte de um contexto que excede o bairro, deixando na sombra a cosmologia jurídica-política da qual fazem parte e em cujas relações estão ligados e se comunicam com outros de diferentes modos (os consumidores, os agentes alfadengários, as polícias e os "patrões", donos da mercadorias). Nessa cosmologia jurídico-polítíca que multiplica alteridades nas quais as crianças participam por meio de seus relacionamentos na escola e no bairro, apreendemos um autoentendimento construído por elas que responde, duplica, compartilha e resiste de modo inventivo a esse contexto, incluindo essa construção no relacionamento delas conosco, como pesquisadoras
\end{abstract}

\title{
Considerações finais
}

As interações e as percepções construídas pelas crianças nesse universo singular denotam que elas vivenciam sentimentos vívidos de ambiguidades, dados pelo cuidado e pela proteção dos adultos, principalmente das mães. Isso pode ser visto nas recomendações dos pais para que brinquem em casa e no quintal. Assim, como observamos entre elas, ser criança na comunidade é assistir televisão, jogar videogame, brincar de casinha, jogar bola e brincar de bonecas. Ficar e brincar em casa, na percepção das crianças, deve-se à preocupação dos pais com o movimento perigoso do bairro. As crianças são colaborativas no cotidiano vivido em casa, mas igualmente vigiadas, pelo contexto particular em que vivem. Tais vivências expressas no cotidiano do bairro emergem no espaço da escola; e a escola interage e é parte do bairro, adaptando seus horários e suas atividades ao ritmo de vida do bairro e das famílias de seus alunos. Como se observa, a inserção da escola no contexto é ambivalente: por um lado ela está inserida no bairro adaptando suas atividades a ele, por outro impede que a vivência cotidiana do bairro seja explícita, pois as reticências e silêncios ocorrem nas interações entre as crianças e os professores. Todos "compartilham" e "conhecem" no espaço escolar o modo de existência 
"Tomar cuidado com o que eu falo": ser criança na escola, ficar e brincar em casa

singular, mas ele é pouco ou nada explicitado. Alguns professores não sabem o que fazer ou dizer diante das percepções e angústias trazidas pelas crianças.

Para as crianças, os moradores do Jardim Jupira não são "muambeiros" (vistos como intrusos inoportunos quando vão ao bairro apressados, prejudicando principalmente o trânsito); não são "chefes" e nem "patrões" de rede que transportam mercadorias e nem as compram. O bairro tem múltiplas atividades, igualmente múltiplas são as diferentes moralidades. Os moradores parecem estar envolvidos em um contorno social construído por um compromisso ético, cumplicidade e união entre eles; demonstram um forte vínculo de proteção, troca e retribuição entre os familiares de laços sanguíneos e também com os vizinhos considerados como parentes. Se suas atividades são ilegais, porque incorrem no crime de sonegação fiscal, contrabando e descaminho, para eles são atividades legítimas e rotineiras, sobretudo porque transportam as mercadorias compradas por outros.

Resta mencionar que esse autoentendimento, como todo autoentendimento, é sempre derivado de diversas relações que se ligam a despeito de diferentes origens, em seus desdobramentos e em seu diálogo com outros de diferentes modos, seja estabelecendo analogias, contrastes ou comparações. Assim, por exemplo, o autoentendimento das crianças a respeito das atividades de transporte de mercadorias se comunica com o autoentendimento da Justiça, expresso nos regulamentos, qualificadores das atividades como crimes de contrabando e descaminho. Comunica-se com o dos consumidores, que fazem dos "muambeiros" ou "laranjas" mediadores para um consumo de mercadorias "justo" e aceitável, mesmo sendo ilegal, pois justificado pela alta taxa tributária no Brasil. Na cultura pública, transmitida por grandes jornais e outras formas de mídias nacionais e locais, as atividades ilícitas na fronteira são vistas como forma de descontrole, e a linguagem desses mesmos veículos aproxima-se da linguagem jurídica. Para o auto entendimento sociológico local, trata-se de um modo de vida socioeconômico e espacial, dotado de relações de produção reguladas por diferentes sistemas jurídicos, mesmo subordinado ao sistema capitalista global (Abínzano, 2013). O comércio ilícito se vê atravessado por redes transnacionais, regionais e extrarregionais ( Catta, 2011 e Cardin, 2011). Para quem vive dessas atividades, trata-se de um trabalho visto como "informal", porque não ë "reconhecido perante a lei, 


\section{Regina Coeli Machado e Silva \\ Marisa Elizabete Cassaro Godoy}

não tem registro. Seria ilegal para o autoentendimento dessas pessoas se elas tivessem tirando de alguém, roubando ou revendendo (Barros, 2008). "Relativizar essas práticas é admitir as contradições de um sistema econômico e político que cria subgrupos com interesses quase opostos" (FONSECA, 2000, p.14).

O autoentendimento dessas crianças expressa as moralidades conflitantes que emergem das relações entre o bairro, a escola, a cidade e a fronteira derivadas, por um lado, dos preconceitos contra as ocupações dos adultos e, por outro, dos processos educativos da escola, forma institucional que reitera os discursos da legalidade. Assim, ser criança nesse contexto é ficar e brincar em casa, sob controle e vigilância, expressando a preocupação dos pais com os perigos do bairro envolvidos no transporte de mercadorias e, fora do bairro, é manter sempre que possível, sigilo sob seu modo de vida.

As crianças expressam as atividades do transporte de mercadorias sobretudo como movimento e usam verbos para qualificá-las como "carregar", "passar", "puxar" e "guardar". As ocupações possuem um vocabulário próprio, como "olheiro", indicando a vigilância recíproca entre moradores e as forças repressoras do "contrabando", "lancheiro", que pilota barcos no rio, "barranqueiro", que trabalha às margens no rio, "passeiro", que transporta as mercadorias. Da força expressiva, abrangência e pertinência dos significados revelados por elas emerge um mundo possível, visto e vivido além da escola, que intensifica as fronteiras geográficas e simbólicas onde habitamos.

A construção das fronteiras simbólicas, impostas pelos limites do rigor dos adultos no cuidado com os filhos, pelo cerceamento ao acesso à rua, como medida de proteção, e pelas tentativas de isolamento da maioria das crianças em relação aos acontecimentos do bairro são pouco eficientes. Intensificadas, essas práticas adquirem a figura do sigilo, inscrevendo as crianças em interações marcadas por um envolvimento comprometido e mantido diante do "perigo", potencial ou imediato. O sigilo, portanto, encoberto pelo silêncio, é um limite invisível entre esse envolvimento comprometido e a identificação delas frente aos "outros", fora do bairro (professores, policiais, funcionários públicos etc.). Se o silêncio é a parte mais evidente na dinâmica relacional entre crianças e adultos fora do bairro, o sigilo tem como efeito na vida das crianças o cerceamento de sua voz, fora do bairro, e o cerceamento de sua livre circulação e de suas ações, 
"Tomar cuidado com o que eu falo": ser criança na escola, ficar e brincar em casa

dentro do bairro, expostas aos "perigos" da movimentação das mercadorias e aos riscos envolvidos na repressão a ela considerada ilegal. Isto é, longe da fórmula corriqueira do autoentendimento compartilhado, com diferenças sutis, por grupos em posições diferentes para se referir ao trabalho de transporte de mercadorias na fronteira, é que esse trabalho é legítimo e ilegal.

Como se pode apreender, há diferentes auto entendimentos em relação, dados pela circularidade de alteridades advindas das posições sociais em relação a essas formas de vida, o que definimos como cosmologia jurídico-política. Interrogar a respeito das formas de vida de pessoas que vivem, por meio do trabalho, a disjunção entre o ilegal e o legítimo, entre o ilícito e o rotineiro, não supõe, a priori e necessariamente, uma defesa desse modo de vida e menos ainda acatar a obviedade das definições dessas atividades como ilegais. O que quisemos aqui foi precisamente apreender outras formas de experimentação ou invenção de relações locais convivendo com dispositivos jurídico-políticos, ao mesmo tempo em que elas emergem precisamente dessa convivência, de modo tenso e inventivo e reveladas pelas crianças na escola.

\section{Referências bibliográficas}

ABÍNZANO, Roberto Carlos. Estudos Antropológicos en de la région de fronteras: cuesttiones de teoria e metodologogia. Ideação. Vol 15, n. 2. Cascavel: Edunioeste, 2013.

ALBUQUERQUE, José Lindomar C. A dinâmica das fronteiras: os brasiguaios na fronteira entre o Brasil e o Paraguai. São Paulo: Annablume, 2010.

ALCÂNTARA, Nohara. HISTÓRIA DE VIDA. Blog Educação de Valor. Projeto Identidade. Postado em 04/04/2011. Disponível em: http://educacaodevalor.blogspot.com.br/search/label/Projeto\%20Identidade . Acesso em 22/05/2014.

ALDERSON, P. Children as researchers: the effects of participation rights on research methodology. In: CHRISTENSEN, P.; JAMES, A. (Ed.). Research with children: perspectives and practices. London: Falmer, 2000, p. 241-255.

ANDRÉ, Marli Eliza Dalmazo Afonso. Tendências atuais da pesquisa na escola. Caderno Cedes ,Vol.18, n. 43, Campinas, 1997. Disponível em: http://dx.doi.org/10.1590/S0101-32621997000200005. Acesso em 02/11/2014. 


\section{Regina Coeli Machado e Silva \\ Marisa Elizabete Cassaro Godoy}

BARROS, Adriane dos Santos. A informalidade dos laranjas na fronteira Brasil/Paraguai. História na fronteira. Vol 1, n.1. Foz do Iguaçu, jul./dez.2008. BORGES, Antonádia e KAEZER, Verônica. El Rincón de los niños: un abordaje etnográfico sobre l@as niñ@s y sus ensayos políticos. MILSTEIN, D. et AL. Encuentros etnográficos y espacios compartidos. Buenos Aíes: Miño y Dávila, 2011.

BRASIL, Ministério do Desenvolvimento Agrário e Social. Disponível em: $<$ http://mds.gov.br/assuntos/bolsa-familia/o-que-e> Acesso em 06/08/2016.

CARDIN. Eric G. Ação racional e cotidiano: notas para o estudo dos trabalhadores da Tríplice Fronteira. In Santos, M.E.P. e Silva, R.C.M e.(orgs) Cenários em perspectiva: diversidades na Tríplice Fronteira. Cascavel: EDUNIOESTE, 2011.

- Laranjas e sacoleiros na tríplice fronteira: um estudo da precarização do trabalho no capitalismo contemporâneo. Cascavel: EDUNIOESTE, 2011.

CATTA, Luiz Eduardo. O cotidiano de uma fronteira: a perversidade da modernidade. Cascavel, EDUNIOESTE, 2002.

- A face da desordem: pobreza e estratégias de sobrevivência em uma cidade de fronteira. (Foz do Iguaçu/1964-1992). São Paulo: Blucher Acadêmico, 2009.

COHN, Clarice. Crescendo como um Xikrin: uma análise da infância e do desenvolvimento infantil entre os Kayapó-Xikrin do Bacajá. Revista de Antropologia, 43 (2): 195-222, $2000 . \quad$ Disponível em: http://www.scielo.br/scielo.php?script=sci_arttext\&pid=S0034-77012 000000200009\&lng=en\&tlng=pt . Acesso em fev./2016.

. Antropologia da criança. Rio de Janeiro: Jorge Zahar Ed. 2005.

FAVRET-SAADA, Jean. Ser afetado. SIQUEIRA, Paula. Cadernos de Campo (São Paulo, 1991), São Paulo, v. 13, n. 13, p. 155-161, mar. 2005. ISSN 2316$9133 . \quad$ Disponível em: http://www.revistas.usp.br/cadernosdecampo/article/view/50263. Acesso em: 30/07/2016.

FONSECA, Claudia. Antropologia e Psicologia: apontamentos para um diálogo aberto. In: KESSLER, Carlos Henrique (Org.) Trama da clínica psicanalítica em debate. Porto Alegre: UFRGS, 2004.

Família, fofoca e honra: etnografia de relações de gênero e violência em grupos populares. Porto Alegre: Ed. Universidade/ UFRGS, 2000. 
"Tomar cuidado com o que eu falo": ser criança na escola, ficar e brincar em casa

GODOY, Marisa Elizabete Cassaro. Ser criança em uma escola pública do lado brasileiro da fronteira Brasila/Paraguai: dos feixes atando pontes. Dissertação de mestrado. Texto digitado. Foz do Iguaçu: Unioeste, 2015.

GODOY, Maria Elisabete Cassaro e SILVA, Regina Coeli Machado e. Lá embaixo: percepções das crianças de uma escola pública sobre o cotidiano do bairro onde vivem, do lado brasileiro da fronteira. Revista Lingua e Letras. Vol.15, n. 28, 2014. Disponível em: http://erevista.unioeste.br/index.php/linguaseletras/article/view/11206. Acesso em 03/07/2016.

HANSON, Karl. Separate chilhood laws and the future of society. Law, Culture and Humanities, June 2016, 2014, v.12 (2). 195-205. DOI: 10.1177/1743872114529502. Acesso em 03/07/2016.

HARDMAN, Charlotte. Can there be an anthropology of chidren? Childhood 8(4). Sage Publications, 2001. p. 501-517.

INGOLD, Tim, Become persons: consciousness and sociality in human evolution, Cultural Dynamics, 4 (3), 1991, p. 355-378.

. Technology, language, intelligence: a reconsideration of basic concepts, IN: K. R. Gibson e T. Ingold (orgs.), Tools, Language and Cognition in Human Evolution. Cambridge, Cambridge University Press, 1993, p. 449472 .

Culture, perception and cognition, IN: T. Ingold, The Perception of the Environment: Essays on Livehood, Dwelling and Skill. Londres, Routledge, 2002, p. 157-171.

JONES, Graham M. Secrecy. In Annual Review in Anthropology. Vol. 43, p. 53-69, 2014.

LAVE, Jean. Cognition in Practice: Mind, Mathematics and Culture in Everyday Life. Cambridge, Cambridge University Press, 1988.

$164,1996$.

Teaching, as learning, in practice, Mind, Culture and Activity, 3: p. 149-

- Hacia una ontología social del aprendizaje. Revista de Estudios Sociales, 40: p. 12-22, 2011.

LAVE, Jean, e Etienne WENGER. Situated Learning: Legitimate Peripheral Participation. Cambridge, Cambridge University Press, 1991.

LEVINE, Robert A. Etnographic studies of childhood: a historical overview. American Anthropologist. Vol. 109, n.2. june 2007 p. 247-260. Disponível em: http://onlinelibrary.wiley.com/doi/10.1525/aa.2007.109.2.247/pdf. Acesso em 03/07/2016. 


\section{Regina Coeli Machado e Silva \\ Marisa Elizabete Cassaro Godoy}

MILSTEN, Diana et al. Encuentros etnográficos com niñ@s y adolescentes: Entre tiempos y espacios compartidos. Buenos Aíes: Miño y Dávila, 2011.

. La nación en la escuela. Viejas y nuevas tensiones políticas. Buenos

Aires: Miño y Dávila, 2009.

Children as co-researchers in anthropolical narratives in

education. Etnography and education. 5:1, p 1-5, 2010.

ORTNER, Sherry B. Theory in anthropology since the sixties, Comparative Studies in Society and History, 26 (1): 167-173, 1984.

PIRES, Flávia. O que as crianças podem fazer pela antropologia?, Horizontes Antropológicos, 16 (34): 137-157, 2010. Disponível em: http://www.scielo.br/scielo.php?script=sci__ arttext\&pid=S0104 71832010000200007\&lng=en\&nrm=iso . Acesso em jan/2016.

PIRES-SANTOS, Maria Elena et al . Vendo o que não se enxergava: condições epistemológicas para construção de conhecimento coletivo e reflexivo da língua(gem) em contexto escolar. DELTA, São Paulo, v. 31, n. spe, p. 35-65, ago/ 2015 . Disponível em: http://www.scielo.br/scielo.php?script=sci_arttext\&pid=S0102-

44502015000300004\&lng=pt\&nrm=iso. Acesso em 03/07/2016.

PORTAL DO BOLSA FAMÍLIA. Disponível em: http://www.bolsafamilia.datasus.gov.br. Acessado em 03/12/2013

PORTAL INEP - Instituto Nacional de Estudos e Pesquisas Educacionais Anísio Teixeira. Disponível em: http://www.portal.inep.gov.br . Acesso em 10/12/2013.

PROCEDIMENTO DE DESENHO DE FAMILIA COM OUTRAS ESTÓRIAS. Blog Educação de Valor. Projeto Família. Postado por Nohara Alcântara em 04/04/2011. Disponível em: http://educacaodevalor.blogspot.com.br/search/label/Afamília. Acesso em 22/05/2014.

PROJETO POlítico PEDAGÓGICO. Escola Municipal Ponte da Amizade. Educação Infantil e Ensino Fundamental. Foz do Iguaçu, 2012.

QVORTRUP, Jens. A infância enquanto categoria estrutural. Educação e Pesquisa, 36 (2): 631-644, 2010. disponível em: http://www.scielo.br / scielo.php?script=sci_arttext\&-pid=S1517-

97022010000200014\&lng=en\&nrm=iso\&tlng=pt . Acesso em jan/2016.

REIMANN, Valdirene. As crianças da ponte: o trabalho de crianças $e$ adolescentes no comércio fronteiriço de Foz do Iguaçu PR. Dissertação de 
"Tomar cuidado com o que eu falo": ser criança na escola, ficar e brincar em casa

Mestrado do Programa de Pós-graduação Stricto Sensu em Sociedade Cultura e Fronteiras. UNIOESTE, 2012.

SIMMEL, George. The sociology of secrecy and of secret societies. American Journal of Sociology. Vol 11, Issue 4 (jan.1906). p 441-498. Disponível em: http://www.d.umn.edu/cla/faculty/jhamlin/4111/Readings/SimmelSecrecy. pdf. Acesso em 09/08/2016.

SILVA, Regina Coeli Machado e. O Estado-Nação se (des)fazendo no cotidiano vivido em uma escola de fronteira Brasil, Argentina e Paraguai. Disponível em: http://www.enadir2015.sinteseeventos.com.br/simposio/view?ID_SIMPOSI $\mathrm{O}=17$. Acesso em fev/2015.

. Vidas, Nações e Estados se fazendo nas fronteiras entre Brasil, Paraguai, Argentina. Revista Ideação do Centro de Educação Letras e Saúde da UNIOESTE. Campus de Foz do Iguaçu. V. 15 n. 2 p. 10-32. $2^{\circ}$ semestre de 2013.

. Do Ipê Roxo na Cidade Nova: experiência etnográfica e aprendizagem situada. Etnográfica [Online], vol. 20 (1) | 2016, Online desde 04 Março 2016. Disponível em: http://etnografica.revues.org/4225 ; DOI : 10.4000/etnografica.4225. Acesso em 03/07/2016.

TOREN, Christina. Making history: the significance of childhood cognition for a comparative anthropology of mind, Man, 28: 461-478, 1993. DOI: $10.2307 / 2804235$

. Becoming a Christian in Fiji: an ethnographic study of ontogeny.

The Journal of the Royal Anthropological Institute, 9 (4): 709-727, 2003. Disponível em: http://www.jstor.org/stable/3134707. Acesso em jan/2016.

. A matéria da imaginação: o que podemos aprender com as idéias

das crianças fijianas sobre suas vidas como adultos. Horizontes Antropológicos, 34: 19-48, 2010. DOI : 10.1590/S0104-71832010000200002

__ Antropologia e psicologia. Revista Brasileira de Ciências Sociais, 27 (80): 21-36, 2012. Disponível em: http://www.scielo.br/pdf/rbcsoc/v27n80/v27n80a02.pdf . Acesso em jan/2016. DOI : 10.1590/S0102-69092012000300002

TRIBUNA POPULAR, jornal online. Disponível em: http://www.jtribunapopular.com.br. Acesso em 09/01/2015.

WAGNER, Roy, 2010, A Invenção da Cultura. Rio de Janeiro, Cosac Naify. VOGEL, Arno; VOGEL, Vera Lúcia; LEITÃO, Gerônimo Emilio A. Como as crianças veem a cidade. Rio de Janeiro: Pallas Flacso: UNICEF, 1995. 
Regina Coeli Machado e Silva

Marisa Elizabete Cassaro Godoy

ZAMBERLAN, Jurandir. Foz do Iguaçu em contexto de mobilidade. Paróquia Bom Jesus do Migrante. Jurandir Zamberlan, Joel Ferrari, Giovanni

Corso, Joaquim R. Filippin. Porto Alegre: Solidus, 2007 